\title{
From Nature versus Nurture, via Nature and Nurture, to Gene x Environment Interaction in Mental Disorders
}

Wermter AK ${ }^{1}$, Laucht $\mathrm{M}^{2}$, Schimmelmann B ${ }^{3}$, Banaschewski $\mathrm{T}^{2}$, Sonuga-Barke E.J.S. ${ }^{4,5}$, Rietschel $\mathrm{M}^{6}$, Becker $\mathrm{K}^{1,2}$

${ }^{1}$ Department of Child and Adolescent Psychiatry and Psychotherapy, Philipps-University of Marburg, Hans-Sachs-Str. 6, D-35039 Marburg, Germany

${ }^{2}$ Department of Child and Adolescent Psychiatry and Psychotherapy, Central Institute of Mental Health, Postbox 1221 20, D-68072 Mannheim, Germany

${ }^{3}$ University Hospital of Child and Adolescent Psychiatry, University of Bern, Effingerstr. 12, 3011 Bern, Switzerland

${ }^{4}$ Developmental Brain-Behaviour Laboratory, Department of Psychology, University of Southampton, Southampton, S017 1BJ U.K.

${ }^{5}$ Department of Experimental Clinical and Health Psychology, University of Gent, Henri Dunantlaan 2, B-9000 Gent Belgium

${ }^{6}$ Division of Genetic Epidemiology in Psychiatry, Central Institute of Mental Health, Postbox 1221 20, D-68072 Mannheim, Germany

Column-Title: Gene-Environment Interaction

\section{Correspondence to:}

Prof. Dr. Katja Becker, Department of Child and Adolescent Psychiatry and Psychotherapy, Philipps University Marburg, Hans-Sachs-Str. 6, D-35039 Marburg, Germany; telephone: +49-(0)6421-586 6260; fax: +49-(0)6421-586 8975; e-mail: Katja.Becker@med.uni-marburg.de 


\section{Abstract}

2 It is now generally accepted that complex mental disorders are

3 the results of interplay between genetic and environmental

4 factors. This holds out the prospect that by studying GxE

5 interplay we can explain individual variation in vulnerability

6 and resilience to environmental hazards in the development of

7 mental disorders. Furthermore studying GxE findings may give

8 insights in neurobiological mechanisms of psychiatric disorder

9 and so improve individualized treatment and potentially

10 prevention. In this paper we provide an overview of the state of

11 field with regard to GxE in mental disorders. Strategies for GxE

12 research are introduced. GxE findings from selected mental

13 disorders with onset in childhood or adolescence are reviewed

14 (such as depressive disorders, attention-deficit/hyperactivity

15 disorder [ADHD], obesity, schizophrenia and substance use

16 disorders). Early seminal studies provided evidence for GxE in

17 the pathogenesis of depression implicating 5-HTTLPR, and

18 conduct problems implicating MAOA. Since then GxE effects

19 have been seen across a wide range of mental disorders (e.g.,

20 ADHD, anxiety, schizophrenia, substance abuse disorder)

21 implicating a wide range of measured genes and measured

22 environments (e.g., pre-, peri- and postnatal influences of both a

23 physical and a social nature). To date few of these GxE effects

24 have been sufficiently replicated. Indeed meta-analyses have

25 raised doubts about the robustness of even the most well studied

26 findings. In future we need larger, sufficiently powered studies

27 that include a detailed and sophisticated characterisation of both

28 phenotype and the environmental risk. 


\section{Key Words:}

2 Gene-Environment Interaction, Depressive Disorders, ADHD,

3 Obesity, Schizophrenia, Substance Use Disorders

4

5 


\section{Introduction}

2 Recent progress in the development of powerful new techniques

3 for locating and identifying human susceptibility genes and

4 genetic variations contributing to common diseases has created

5 new opportunities to advance our understanding of the etiology

6 of mental disorders. Two approaches, linkage and association

7 analyses, have been applied to identify and study genetic effects

8 across a number of mental disorders. These disorders include

9 attention-deficit/hyperactivity disorder (ADHD), autism

10 spectrum disorders, mood disorders, substance use disorders,

11 schizophrenia, eating disorders, obesity, and anxiety disorders.

12 However, despite initial optimism, few susceptibility genes (i.e.

13 predisposing sequence variations) have been replicated with

14 some consistency. Even for replicated findings the effects are

15 very small: Taking all risk genotypes into account explains only

16 a small fraction of the variation in the expression of a disorder.

17 There are several possible explanations for this. One is that

18 gene-environment interactions (GxE) have so far been largely

19 ignored in the design and analyses of genetic studies. This has

20 hampered the detection of significant genetic effects operating

21 in those exposed to one environment and not another [69]. This

22 notion is supported by the growing body of evidence for the

23 contribution of genetic effects in explaining individual

24 variability in response to all kinds of environmental hazards

$25[68,82,83]$. Because of this type of work it is nowadays

26 generally accepted that complex mental disorders require an

27 understanding of the interplay between genetic and

28 environmental factors. This GxE hypothesis is

29 neurobiologically plausible and is supported by a growing body

30 of evidence (e.g., there are formal genetic studies in its favour 
1 [51]). However, some researchers remain skeptical and call for

2 more robust replication of initial results [70]. Clearly much

3 more work is needed to establish (i) the conditions under which

4 GxE occur; and (ii) the mechanisms that drive the GxE effects.

5 Why do some genetic variants have effects only in the presence

6 of a particular environmental exposure and/or vice versa [64].

7 The article starts with an overview of the impact as well as the

8 limitations of GxE studies in general, This is followed by more

9 detailed information about GxE research findings in some

10 selected mental disorders with onset in childhood or

11 adolescence.

13 The Importance of Gene-Environment Interplay in the

\section{Etiology of Mental Disorders}

$15 \mathrm{GxE}$ provides a potential explanation of the individual 16 differences in responses to environmental influences. GxE 17 occurs when the effect of exposure to an environmental 18 pathogen on a person's health is conditional on the genotype 19 [19]. For example, children exposed to an environment stressor 20 known to increase risk for a certain psychiatric disorder (e.g., 21 high family adversity) are at a higher risk for that disorder if 22 they carry particular gene variants which renders them more 23 susceptible to that stressor (see figure 1). --please add figure 1 about here-Alternatively children carrying a genotype known to increase susceptibility for a specific mental disorder may only develop that disorder if they are exposed to specific environmental risk factors (see figure 2). 
1 According to these models on the one hand, differences in

2 individual genetic make-up are responsible for the differences

3 between individuals with regard to resilience or vulnerability to

4 the similar environmental pathogens. On the other hand,

5 outcomes among individuals who do not vary in terms of the

6 susceptibility allele may be determined as a function of

7 variability in environmental exposure. In other words, GxE

8 effects index a genetically determined liability to specific

9 environmental influences. One example with one dichotomous

10 genotype (present or absent) of a causative genetic mutation and

11 one dichotomous environmental exposure (exposure versus

12 non-exposure) is phenylketonuria (PKU) [46]. The development

13 of PKU needs both homozygote mutations in the causative gene

14 encoding phenylalanine hydroxylase, and exposure to

15 phenylalanine [53]. An example for a complex genetic disorder

16 is the alcohol flush reaction after alcohol ingestion in

17 individuals with a genetic variant leading to lowered activity of

18 the aldehyde dehydrogenase (ALDH), a variant which is mainly

19 observed in the Asian population [102]. Carriers of this variant

20 also can develop alcohol dependence after exposure to alcohol,

21 but they are at a much lower risk to do so as compared to those

22 who do not carry this variant. GxE processes will necessarily be

23 more complex if several gene variants and types of

24 environmental exposure contribute to susceptibility for a

25 disease [46], as is almost certainly the case for mental disorders.

26 The frequent failures to replicate initial genetic findings of

27 association between genotypes and disease might be, among

28 other factors (such as differences in gender ratio, ethnicity, age

29 or comorbid conditions), caused by ignoring simple differences

30 with respect to exposure to relevant environmental factors. If, 
1 for example, association has been found in a sample with

2 frequently exposed subjects but not in those infrequently

3 exposed, and exposure has not ascertained, the source of non-

4 replication will remain elusive [69]. GxE studies thus might

5 shed light into the genetically mediated effects underlying both

6 resilience and vulnerability. This might help us to understand

7 and resolve the inconsistency in results found in classical

8 association studies with regard to correlations between

9 disorders and genotypes. GxE findings may also provide helpful

10 insights into the causal processes in pathogen-to-disorder

11 pathways and therefore shed light on the underlying mechanism

12 of "how an environmental factor external to the person gets

13 under the skin" to result in a mental disorder [69]. As these

14 pathways will vary between disorders, genes have the potential

15 to offer valuable clues to these disorder-specific causal

16 mechanisms [69]. Understanding GxE mechanisms may also

17 provide useful hints with regard to prevention of, and

18 intervention for, mental disorders. New findings in GxE may

19 advance the development of individual therapeutic strategies

20 and lead to pharmacogenetic-based therapeutic innovation [91,

21 94]. Moffitt and co-workers [69], along with others, emphasize

22 the importance of GxE and highlight the relevance of strategic

23 gene-environment research.

\section{Limitations and Pitfalls in Studying GxE}

Despite the self-evident value of the GxE strategy there are several methodological challenges. There is the possibility of overestimating effects and false positive findings because of

29 multiple testing and/or data dredging. Along with difficulties in

30 statistical power $[16,63,107]$, the susceptibility to artifacts in 
1 GxE research has to be kept in mind. Statistically significant

2 interactions are sensitive to alterations in the definition and

3 scaling of the variables being examined: artefactual interactions

4 can be produced by altering scaling [68]. Another problem is

5 how to disentangle GxE from gene-environment correlations

6 (rGE), defined as the probability of a subject's exposure to an

7 environmental pathogen resulting in the association of measures

8 of environmental exposure with genetic variation [19, 87]. GxE

9 may be affected by co-occurring rGE, in which, according to

10 Plomin and co-workers, one can differentiate between passive,

11 active, and evocative rGE [76]. Passive rGE occur because the

12 parents pass on their genes and provide their rearing

13 experiences which may be genetically influenced, e.g., parental

14 qualities [89]. Active-evocative rGE arise because their

15 behaviour makes people select their environments and

16 influences other peoples' responses to them [89]. Rutter \&

17 Silberg viewed both, GxE and rGE, as different forms of gene-

18 environment interplay [88]. Furthermore, one needs to bear in

19 mind the role of epigenetic effects of environmental influences

20 on gene expression or chromosomal structure and from

21 variations in heritability according to environmental

22 circumstances $[68,83,87]$. For more details on methodological

23 challenges and statistical pitfalls see $[28,30,37,46-48,64,70$,

$2480,81,85,108]$. In order to address these and other problems

25 Moffit and co-workers [68, 69] defined seven strategic steps for

26 research into measured GxE (see Table 1). More detailed

27 information pertaining to the strategies for careful deliberate

28 GxE hypothesis testing is summarized in $[19,68,69,85]$. 
1 GxE Findings for Selected Mental Disorders with Onset in

2 Childhood and Adolescence

3 Initial indications - seminal studies by Caspi and Moffitt: The

4 first molecular genetic evidence for $\mathrm{GxE}$ in child and adolescent

5 psychiatric conditions comes from two classic studies by the

6 research group of Caspi and Moffit [18, 21]. These dealt with

7 conduct disorder, depression and emotional problems. The first

8 study included 442 male participants and demonstrated that the

9 effect of childhood maltreatment was moderated by a functional

10 polymorphism in the gene encoding the neurotransmitter-

11 metabolizing enzyme monoamine oxidase A (MAOA) [18].

12 Carriers of the low-activity MAOA genotype who were severely

13 maltreated more often developed conduct disorder, antisocial

14 personality and adult violent crime than children with a high-

15 activity MAOA genotype [18]. Several researchers carried out

16 studies to replicate this interaction [38, 42, 54, 74, 112]. Despite

17 a number of non-replications a meta-analysis revealed an

18 overall significant effect [54].

19 The second key study by this group examined GxE in the

20 pathogenesis of depression [21]. In this prospective-longitudinal

21 study the functional polymorphism 5-HTTLPR in the promoter

22 region of the serotonin transporter gene (SLC6A4) was found to

23 moderate the influence of stressful experiences occurring over a

24 5-year period before onset of depression [21]. The carriers of

25 one or two copies of the low expressing short allele of the 5-

26 HTTLPR exhibited more depressive symptoms, diagnosable

27 depression, and suicidality following stressful life events than

28 individuals homozygous for the long allele [21]. Additionally,

29 Caspi and co-workers [21] detected an interaction between 5-

30 HTTLPR and childhood maltreatment over the period between 
1 ages 3 to 11 years. This interaction showed that childhood

2 maltreatment predicted adult depression only among individuals

3 carrying a short allele of the 5-HTTLPR but not among

4 individuals homozygous for the long allele [21].

$6 \quad$ Depressive Disorders

7 Following the striking initial findings of Caspi and co-workers

8 [21] studies have replicated the 5-HTTLPR GxE in depression

9 (reviewed in [108]). There have also been a number of failures

10 to replicate [108]. A recent meta-analysis by Munafo and co-

11 workers however, concluded that the effects of 5-

12 HTTPLR x serious life events (SLE) on risk of depression are

13 compatible with chance findings [70], and a very recent meta-

14 analysis by Risch and co-workers including published data from

1514 studies [22-24, 33, 39, 41, 55, 59, 65, 66, 77, 101, 103, 111]

16 yielded no evidence for an association of the 5-HTTLPR

17 genotype alone or in interaction with stressful life events with

18 an elevated risk of depression [80]. In addition, a gender-

19 specific meta-analysis revealed no sex dependent interaction

20 effects [80]. The failure of these meta-analyses to confirm the

21 initial results of Caspi and co-workers [21] may indicate that

22 there actually is no association. Alternatively, sample

23 differences in background genetic and environmental factors

24 could underlie the discrepant findings [80] (see limitations).

25 They could also be explained by the limited comparability of

26 replication studies due to their highly divergent samples, study

27 designs, measures and analyses [80]. Thus, this inconsistency

28 might be caused by methodological differences in the way of

29 evaluating the presence of serious life events (SLE) and in

30 different diagnostic instruments applied in depression 
1 (structured face-to-face interviews, questionnaires or

2 telephone/lay interviews, respectively) [29].

3 Further genes have been investigated with regard to GxE and

4 depression. In their case-only design, Drachmann Bukh and co-

5 workers detected an interaction between SLE and the genotypes

6 of 5-HTTLPR and BDNF Val66Met on first episode depression

7 [29]. Additionally, they found no 3-way interaction between

8 SLE, 5-HTTLPR and BDNF Val66Met and no evidence for

9 interactions between SLE and polymorphisms in COMT, TPH1,

10 ACE, 5-HTR2A, and 5-HTR2A, respectively, on depression.

11 According to the authors these results add evidence to the

12 opinion that genes influence the liability to depression not only

13 by main effects on risk but also by control of sensitivity to the

14 pathogenic effects of the environment [29]. This is plausible as

15 variation in the 5-HTTLPR polymorphisms may modulate the

16 serotonergic response to stress [108]. Further evidence for this

17 hypothesis also comes from fMRI studies which show that

18 carriers of the short allele of 5-HTTLPR polymorphism

19 demonstrate amygdala hyperactivity (meta-analysis see [70])

20 leading to increased corticol release [32]. There is also an initial

21 indication that SLE and 5-HTTLPR polymorphism interact to

22 predict endocrine stress reactivity in a non-clinical sample [2].

23 Adults homozygous for the short allele with a significant

24 history of SLE exhibited markedly elevated cortisol secretions

25 in response to the stressor as compared to all other groups,

26 indicating a significant GxE on endocrine stress reactivity [2].

27 The authors argue that a potential moderating role of HPA-axis

28 hyper-reactivity is a premorbid risk factor that increases the

29 vulnerability for depression in subjects with low serotonin

30 transporter efficiency and a history of severe life events. 
1 In the light of the conflicting GxE results with regard to

2 depression, very carefully designed study approaches for testing

3 of GxE hypothesis are urgently required (see "Limitations and

4 Pitfalls in Studying GxE", see Table 1). Brown and Harris [17]

5 recently outlined inconsistencies with regard to the inclusion of

6 different kinds of environmental factors and the use of a life-

7 course perspective, respectively which may explain the failure

8 of replication of the initial study of Caspi et al [21]. Brown and

9 Harris hypothesized that in the context of childhood

10 maltreatment the 5-HTTLPR polymorphism contributes to GxE

11 via a direct link with the perpetuation of an adult onset of

12 depression [17]. This is consistent with the hypothesis of early

13 changes in brain function associated with the polymorphism in

14 the context of childhood maltreatment [17].

\section{Attention-Deficit/Hyperactivity Disorder (ADHD)}

17 Molecular genetic research on ADHD has produced a number

18 of plausible candidate genes (e.g., Dopamine D4 receptor gene

19 (DRD4), Dopamine D5 receptor gene (DRD5), Dopamine

20 transporter (DAT1) gene and Catechol o-methyltransferase gene

21 (COMT). However, effects of gene variants identified through

22 association studies are small [34], and the association findings

23 with some markers are inconsistent across different studies (i.e.,

24 DATI; reviewed in Banaschewski and co-workers, this issue

25 [6]; [26]). This inconsistency may be due to the moderation of

26 genetic effects by environmental factors that differ between

27 samples. Thapar and co-workers emphasized that phenotypic

28 complexity, as well as differences in the continuity and changes

29 in clinical presentation over ADHD will both be influenced by

30 the interplay between pre- and perinatal as well as psychosocial, 
1 environmental and genetic risk factors [105]. The impacts of

2 environmental factors, such as intrauterine exposure to different

3 drugs (prenatal smoke exposure: [9, 49, 57, 71]; alcohol

4 consumption during pregnancy: $[15$, 57]), psychosocial

5 adversity [58], mothers' expressed emotion (EE) [15, 78, 95,

6 96], severe early deprivation [97, 99, 100], or low birth weight

7 [57, 106], have been studied in GxE investigations. Besides

8 highlighting the role of the environment in modulating genetic

9 effects some of these studies provide evidence for a genetic

10 contribution to continuity of the disorder [31, 56, 92] and the

11 development of comorbid anti-social behaviour [57, 104, 106].

13 Prenatal environmental exposures: A prospective study

14 including 161 children suggested that maternal prenatal 15 smoking modifies the impact of the high-risk 10-repeat (10r)

16 DAT1 allele of the 40-bp VNTR (40 base-pair variable number

17 of tandem repeats) polymorphism in the 3'UTR of the DATI

18 gene [49]. Symptoms of hyperactivity, impulsivity as well as

19 oppositional behaviour were increased among children who

20 were homozygous for the DAT1 10r allele, but only if those

21 children were exposed to prenatal maternal smoking [49].

22 However, Neuman and co-workers [71] failed to replicate this

23 GxE between prenatal smoking exposure and the DATl 10-

24 repeat allele in children with a diagnosis of ADHD, although

25 the odds for a DSM IV-diagnosis of ADHD was 1.8 times

26 greater in children whose genotype at the DAT1 3'VNTR

27 contained the 9-repeat (9r) allele and whose mother smoked

28 during pregnancy than for twins who had neither of these risk

29 factors [71]. Apart from the possibility that the sample was too

30 small this failure to replicate may be due to defining tobacco 
1 use in pregnancy as smoking more than 20 cigarettes a day. In a

2 longitudinal study (Mannheim Study of Children at Risk)

3 including 305 adolescents at age 15 years, Becker and co-

4 workers [9] partly confirmed the findings of Kahn and co-

5 workers [49], indicating that male homozygous $D A T 1-10$ r allele

6 carriers with prenatal smoke exposure had significantly higher

7 symptoms of hyperactivity-impulsivity than males from all

8 other groups [9]. In contrast, Brookes and co-workers failed to

9 confirm the findings of Kahn and co-workers [49] in a clinical

10 sample [15, 57]. However, this group found evidence for an

11 interaction of a DAT1 risk haplotype and maternal use of

12 alcohol during pregnancy [15]. Langley and co-workers [57]

13 failed to replicate this finding perhaps because they did not

14 genotype both markers of the two marker haplotype of DAT1.

15 On the whole, the reported inconsistencies in studies of GxE

16 (e.g. for ADHD) elucidate the urgent needs of replication

17 studies with both accurate and consistent measures of

18 environmental factors and genetic variants, respectively, and in

19 meta-analyses [57].

21 Postnatal psychosocial adversity: The Mannheim Study of Risk

22 Children also showed that carriers of the DAT1 haplotype

23 comprising the 6-repeat and 10-repeat alleles who grew up in

24 greater psychosocial adversity exhibited significantly more

25 inattention and higher hyperactivity-impulsivity than those with

26 other genotypes/haplotypes or those living in less adverse

27 family conditions [58]. Two recent papers provide more

28 evidence for the potential role of the psycho-social environment

29 in moderating genetic effects in ADHD. Building on previous

30 work highlighting the role of mothers' expressed emotion (EE) 
1 as a risk factor for poor outcomes in ADHD [78], the first study

2 [96] examined whether the effects of mothers' EE on ADHD

3 children, in terms of the development of conduct and emotional

4 problems, was moderated by genetic variants in a large sub-

5 sample of the IMAGE study [15]. The results suggested that the

6 impact of EE was moderated by the presence of specific DAT1

7 and $5 H T T L P R$ genotypes; children who did not have the DAT1

81 10r/10r or the 5HTTLPR 1/1 genotypes showed an effect of EE

9 on conduct problems. As far as emotional problems were

10 concerned, EE had effects only on those who carried the DATI

$119 \mathrm{r} / 9 \mathrm{r}$ alleles. The second study [99] was carried out as part of

12 the English and Romanian Adoptees (ERA) longitudinal study

13 [86] of the effects of severe early deprivation on development.

14 Previous studies highlighted a link between institutional

15 deprivation and symptoms of ADHD [97, 100], but only in a

16 sub-sample of cases. The results showed that the risk for

17 symptoms of ADHD associated with early institutional

18 deprivation was moderated by the DATI but not the DRD4

19 genotypes, an effect that was first apparent in early, and

20 persisted through mid-adolescence. In both studies it appeared

21 that the genetic make-up altered susceptibility of children to

22 variations in their social environment [10].

23 So far, most GxE studies have employed a candidate gene

24 approach. Studying environmental effects might also be a good

25 strategy for finding potential new genetic markers using purely

26 quantitative strategies such as QTL mapping and genome wide

27 association studies. In the first study of this sort in ADHD,

28 Sonuga-Barke and co-workers [95] conducted a GxE analysis in

29 the context of a genome-wide association scan of the IMAGE

30 study (with 429,981 SNPS available) to identify novel genes 
1 whose effects are moderated by high maternal EE. While no

2 GxE effect reached genome-wide significance, a number of

3 nominal significant effects were observed $\left(p<.10^{5}\right)$ in particular

4 interactions for the genes SLC1A1 and NRG3 represent

5 reasonable candidates for further investigation given their

6 previous association with several psychiatric illnesses.

8 Obesity

9 Obesity is a multi-factorial trait that results from a complex

10 interplay between genes and environment [62]. The surge in the

11 prevalence of obesity occurred within a short period of time

12 suggesting that environmental and behavioural lifestyle factors

13 play a strong role [1]. GxE is gaining increased emphasis due to

14 the large individual differences in responses to the obesogenic

15 environment - individuals with a genetic predisposition to

16 develop obesity will show the greatest weight gain, whereas

17 individuals with genetic "resistance" to obesity will gain little,

18 if any, weight [1]. Environmental factors influence behaviour or

19 lifestyles that determine energy intake or energy expenditure

20 [13]. The differences in individual responses to prevention and

21 treatment strategies, including negative energy balance due to

22 increased energy expenditure and decreased energy intake,

23 seem also to be influenced by individuals' genetic background

24 [14].

25 There have already been numerous efforts to incorporate

26 genetic and/or gene-environment information into obesity

27 intervention and prevention [14]. Some genes have been

28 reported to be associated with weight loss following

29 intervention (e.g. lifestyle change, pharmacological/dietary

30 interventions, and exercise) (summary [14]). For instance, one 
1 polymorphism (rs9939609) in the fat mass and obesity

2 associated gene (FTO) was found to have an effect on the body

3 mass index (BMI), which was replicated in other large samples

4 [62]. Individuals homozygous for the risk A-allele weigh on

5 average about 3-4 $\mathrm{kg}$ more and have a 1.6-fold increased risk of

6 obesity as compared to those who have not inherited a risk

7 allele [62]. Furthermore, there is evidence for a significant FTO

8 genotype $\mathrm{x}$ physical activity interaction, where the physically

9 inactive homozygous carriers of the risk A-allele had an

10 increase in BMI as compared to homozygous carriers of the T-

11 allele [5]. Additionally, other FTO variants showed a significant

12 association with physical activity [79]. However, regarding

13 these GxE with FTO variants and physical activity the findings

14 in different studies are inconsistent. This could be explained

15 among others by the use of different measurements of physical

16 activity (review [4]).

17 Additionally, animal models provide evidence for interaction of

18 genetic background and the impact of perinatal and early

19 childhood environments on metabolic, physiological and

20 neuroendocrine functions and their influence on the

21 development of obesity [61]. Furthermore, the systematic

22 genome-wide association (GWA) study approach holds

23 impressive prospects for the future, provided that the lifestyle

24 factors dietary intake and physical activity are measured

25 accurately because erroneous self-reporting of these factors is a

26 well-known problem (review [4]).

28 Schizophrenia

29 The molecular genetic basis of schizophrenia has been

30 extensively studied. The SzGene database ([3]; 
1 http://www.szgene.org/) provides an up-to-date ranking list of all

2 relevant candidate gene variants (to date in about 30 genes)

3 based on meta-analyses of association studies. Although, as with

4 most complex phenotypes, it is very likely that there may be

5 many rare variants which contribute substantially to the disorder,

6 effect sizes of common single variants are usually small, i.e.

7 average summary odds ratio rarely exceed 1.2 [3]. Evidence for

8 an association between environmental exposure and

9 schizophrenia is most solid for paternal age, migration, obstetric

10 complications (fetal hypoxia and proxies for folate deficiency,

11 maternal infection, or stress during pregnancy), urbanicity, and

12 cannabis use, the latter two particularly in case of exposure

13 during development (see [44] and [109] for review). Findings

14 from twin, adoption, and family studies generally suggest that a

15 synergy between genetic and environmental factors determines

16 psychotic symptoms and disorder, particularly for exposure to

17 migration, urbanicity, obstetric complications, cannabis, stress,

18 and developmental trauma [109] providing a broad range of

19 potential environmental factors for GxE studies. Generally, the

20 neurobiological mechanism driving the effects of these

21 environmental exposures is unclear rendering the selection of

22 potentially relevant genetic variants for GxE studies difficult.

23 A few promising hypotheses do exist and some have been tested:

24 A recent study [72] provided initial evidence that variants in four

25 out of 13 tested candidate genes (AKT1, BDNF, DTNBP1 and

26 GRM3), known to be regulated by hypoxia or involved in

27 vascular functioning in the brain, showed nominally significant

28 interaction with at least one serious obstetric complication event

29 (as a proxy of fetal hypoxia) in 116 patient-trios. Another

30 interesting hypothesis related to obstetric complication is the 
1 potential GxE interaction between prenatal virus exposure and

2 genes involved in the immune response e.g. genes located in the

3 major histocompatibility complex (MHC) region [67]. A first

4 study examining interaction of season of birth and risk variants

5 in the MHC region, however, did not provide any evidence for

$6 \mathrm{GxE}$ [98]. Yet, it is possible that prenatal environmental factors

7 may also alter functioning and structure of relevant genes: e.g.,

8 folate, which is deficient prenatally in some individuals with

9 schizophrenia, is necessary for normal DNA-methylation and

10 this complicates the picture substantially. Thus, epigenetic

11 changes during neurodevelopment have to be considered.

12 In the study of Caspi and co-workers [20], the COMT Val158Met

13 Val allele moderated the risk of developing schizophreniform

14 disorder at age 26 following cannabis use in adolescence.

15 Further, in a double-blind randomized controlled trial [45] the

16 COMT Val allele was associated with an increased sensitivity to

17 the negative cognitive effects of cannabis in patients with

18 psychoses. In another study [110], the COMT Met allele

19 increased the effect of stress on psychotic and affective

20 experiences in daily life in 31 patients with psychosis and

21 cannabis use, but not in non-psychotic cannabis users. There is

22 evidence, derived from animal models (review [44]), suggesting

23 that there are other promising genes (i.e. neuregulin 1 and the

24 genes regulating the dopaminergic and the GABA system) which

25 potentially moderate the effect of cannabis on the risk of

26 schizophrenia. Furthermore, variation in Neuregulin 1 was also

27 reported to moderate the effect of high expressed emotion on the

28 level of unusual thoughts in 200 patients with schizophrenia

29 [52]. 
1 In conclusion, relatively few $\mathrm{GxE}$ interaction studies in

2 schizophrenia are published to date. Promising testable

3 hypotheses based on epidemiological and experimental

4 neurobiological findings are available and need to be examined.

$6 \quad$ Substance Use Disorders

7 Substance use disorders (SUD) are common, multi-factorial

8 disorders, which constitute the leading cause of a wide variety

9 of morbidity and mortality conditions. Both genetic and

10 environmental factors have been implicated in their

11 development, with heritability estimates ranging from 50 to

$1260 \%$ [40]. Moreover, growing evidence suggests that

13 vulnerability to SUD may result from GxE [108]. Among the

14 brain systems involved in the physiological response to drugs of

15 abuse, much attention has been placed on the hypothalamic-

16 pituitary-adrenocortical (HPA) axis. The link between stressful

17 experiences and substance use has long been discussed [93],

18 with the stress-coping model of addiction proposing that

19 substance use serves to regulate stress-related negative affect. A

20 critical role in the regulation of the HPA axis pertains to the

21 corticotropin-releasing hormone (CRH) system, making the

22 genes encoding the $\mathrm{CRH}$ receptors (CRHR1, CRHR2)

23 prominent candidates for GxE studies. Blomeyer and co-

24 workers [12] provided the first evidence that genetic variation

25 in CRHRI moderated the impact of stress on heavy drinking in

26 adolescents. In 15-year-olds, the number of stressful life events

27 during the past three years was found to be significantly related

28 to increasing rates of heavy drinking only among individuals

29 homozygous for the $\mathrm{C}$ allele of the haplotype-tagging SNP

30 rs1876831. Recently, Schmid and co-workers [90] 
1 demonstrated that the CRHRI gene and stressful life events

2 interacted to predict both drinking initiation in adolescence and

3 progression of heavy alcohol use into young adulthood.

4 Findings from animal research support a role for $\mathrm{GxE}$ in the

5 development of excessive alcohol intake. In studies with

6 nonhuman primates, Barr and co-workers [7] revealed that the

7 effects of early stress on alcohol use in later life were

8 conditional on variation in the serotonin transporter gene, with

9 higher consumption only in carriers of the $\mathrm{S}$ allele of 5-

$10 \quad H T T L P R$. Subsequent studies in humans yielded inconsistent

11 results. While Covault and co-workers [27] and Kaufman and

12 co-workers [50] found earlier and heavier alcohol use only

13 among carriers of the $\mathrm{S}$ allele following stressful life events,

14 Olsson and co-workers [75] observed a decrease in binge

15 drinking in risk settings with each additional copy of the $S$

16 allele. Nilsson and co-workers [73] reported that adolescents

17 with poor family relations had an increased risk of alcohol

18 intoxication when carrying the heterozygous LS genotype of 5-

19 HTTLPR. Laucht and co-workers [60] demonstrated that, when

20 exposed to high psychosocial adversity, individuals with the LL

21 genotype exhibited more hazardous drinking.

22 There are several potential reasons for these conflicting

23 findings. One major reason relates to the fact that substance use

24 and SUD represent a heterogeneous phenotype, which may be

25 differentiated into several subgroups (e.g. Cloninger's typology

26 of problem drinking [25]). However, previous studies usually

27 neglected issues of substance use typology. An additional factor

28 that could have contributed to inconsistency may be the

29 heterogeneity wide variety of in measures of environmental

30 adversity used in the different studies. While in several studies 
1 (e.g. [27]) environmental adversity was characterized by

2 exposure to discrete acute events, others focused on chronic

3 difficulties surveyed over a period of years ([73]). However,

4 research on individual differences in biological reactivity to

5 environmental stress has highlighted the duration of a stressor

6 as an important determinant of the stress response.

\section{Conclusions and Implications}

9 There is an emerging consensus that inter-individual variability

10 in an individuals response to environmental exposures can be

11 explained by genetic moderation of such effects. This gene-

12 environment interplay may explain the individuals'

13 vulnerability and resilience to environmental hazards in the

14 development and expression of mental disorders. In this paper

15 we have reviewed the current state of the field with regard to

$16 \mathrm{GxE}$ in a range of disorders with childhood and adolescent

17 onset. We highlight the progress made to date - some candidate

18 GxE processes have been identified for each disorder and in

19 some cases these have been replicated. Nevertheless, these

20 initial GxE findings have to be interpreted with caution. The

21 replication of $\mathrm{GxE}$ findings has in general proved to be

22 challenging - as is also the case for replication of association

23 findings in classical candidate genetic studies. Furthermore, the

24 variance explained by both genetic main effects and GxE

25 effects is invariably small. Initial GxE findings have been

26 challenged by studies using more stringent research designs

27 which better ensure that relations with the measured

28 environmental variables are not influenced by other correlated

29 environmental variables or background common genetic

30 influences [36]. Furthermore, most GxE studies have had only 
1 small samples which may explain why GxE effects are difficult

2 to detect and replicate [36]. Besides possible GxE in the

3 pathogenesis of mental disorders, genetic and environmental

4 effects on the course of a disorder during development are

5 important to consider. Even where GxE does not contribute to

6 the initial development of the disorder, it may have a modifying

7 effect on the developmental course and outcome [104].

8 However, up to now in genetic studies not much attention was

9 paid to the developmental course of a disorder. This is

10 especially true for GxExAge. Thus, future studies in mental

11 disorders should put more emphasis on GxE in the course of

12 development (see [99]).

13 Despite all of these caveats and limitations the study of GxE 14 effects - although still in its infancy - offers a number of 15 exciting possibilities across a range of different domains. It will 16 surely stimulate progress in our understanding of the basic 17 neuroscience on childhood onset psychiatric problems. In future 18 genetic research, GxE studies may provide new insights into 19 biological pathways underlying the pathophysiology of mental 20 disorders. It will also play a crucial role in our growing 21 comprehension/investigation of vulnerability [11] and resilience 22 [35, 84]. Longitudinal $\mathrm{GxE}$ research will be especially 23 important as it can help us to better understand heterogeneity in 24 mental disorders. This in turn can be exploited in both the 25 development of new therapies and the targeting of existing 26 therapies. If we can overcome the methodological challenges 27 that face GxE research, the new insights in biological pathways 28 derived from the investigation of GxE might provide new ways 29 of individualized prevention and therapeutic strategies. 


\section{Acknowledgements:}

2 We are grateful to Jörg Näther for providing the figures. 
1 Table 1: Seven strategic steps for research into measured

2 gene-environment interaction (Table adapted, [69])

\section{Step 1: Consulting quantitative behavioural genetic models of the disorder}

Step 2: Identifying a candidate environmental pathogen for the disorder

Considerations for selecting environmental risks for inclusion in GxE research on mental disorders

disorder develops more frequently in persons exposed to the environmental pathogen compared to those not exposed

$>$ variability in response among people exposed to the same environmental risk

$>$ plausible effect of the environmental risk on biological systems involved in the disorder

$>$ evidence that the putative risk is a true environmental pathogen having causal effects

\section{Step 3: Optimizing measurement of environmental risk}

Considerations for improved environmental measurement to support GxE research

$>$ proximal measures of environmental pathogens

$>$ age-specific environmental pathogens

$>$ the cumulative nature of environmental influences

$>$ retrospective measures of environmental pathogens

Step 4: Systematic genome-wide approach or identifying candidate susceptible genes

Considerations for choosing among candidate genes as they emerge

$>$ common polymorphic variants

$>$ evidence of direct gene-to-disorder association

$>$ functional significance in relation to reactivity to the environmental pathogen

Step 5: Testing for an interaction

$>$ statistical models

$>$ study sampling designs.

$>$ ascertaining the validity of a GxE finding

Step 6: Evaluating whether a GxE interaction extends beyond the initially hypothesized triad of genes, environmental pathogen, and disorder

Step 7: Confirmation in independent samples Meta-analyses

Validation of findings in GxE studies in experimental studies

$>$ animal models (for example [8])

$>$ functional brain imaging studies (for example [43])

$>$ Pharmacogenetics (for example [91, 94])

3 


\section{Figure legends:}

2

3 Figure 1: Environmental factors only lead to a disorder in

4 presence of a specific genetic make-up

5

$6 \quad$ Figure 2: An individual with a susceptible genetic make-up will

7 only develop a disorder if there are additional environmental

8 pathogens

9

10

11 
1. Agurs-Collins T, Bouchard C (2008) Gene-

nutrition and gene-physical activity interactions in the etiology of obesity. Introduction. Obesity

(Silver Spring) 16 Suppl 3:S2-4

2. Alexander N, Kuepper Y, Schmitz A, Osinsky R,

Kozyra E, Hennig J (2009) Gene-environment interactions predict cortisol responses after acute stress: implications for the etiology of depression. Psychoneuroendocrinology 34:1294-1303

3. Allen NC, Bagade S, McQueen MB, Ioannidis JP, Kavvoura FK, Khoury MJ, Tanzi RE, Bertram L (2008) Systematic meta-analyses and field synopsis of genetic association studies in schizophrenia: the SzGene database. Nat Genet 40:827-834

4. Andreasen CH, Andersen G (2009) Geneenvironment interactions and obesity--further aspects of genomewide association studies. Nutrition 25:998-1003

5. Andreasen $\mathrm{CH}$, Stender-Petersen KL, Mogensen MS, Torekov SS, Wegner L, Andersen G, Nielsen AL, Albrechtsen A, Borch-Johnsen K, Rasmussen SS, Clausen JO, Sandbaek A, Lauritzen T, Hansen L, Jorgensen T, Pedersen O, Hansen T (2008) Low physical activity accentuates the effect of the FTO rs9939609 polymorphism on body fat accumulation. Diabetes 57:95-101

6. Banaschewski T, Becker K, Friedel S, Franke B, Coghill D Molecular Genetics in AttentionDeficit/Hyperactivity Disorders: An Overview.

7. Barr CS, Newman TK, Lindell S, Shannon C, Champoux M, Lesch KP, Suomi SJ, Goldman D, Higley JD (2004) Interaction between serotonin transporter gene variation and rearing condition in alcohol preference and consumption in female

8. primates. Arch Gen Psychiatry 61:1146-1152

8. Barr CS, Newman TK, Shannon C, Parker C, Dvoskin RL, Becker ML, Schwandt M, Champoux M, Lesch KP, Goldman D, Suomi SJ, Higley JD (2004) Rearing condition and rh5-HTTLPR interact to influence limbic-hypothalamicpituitary-adrenal axis response to stress in infant macaques. Biol Psychiatry 55:733-738

9. Becker K, El-Faddagh M, Schmidt MH, Esser G, Laucht M (2008) Interaction of dopamine transporter genotype with prenatal smoke exposure on ADHD symptoms. J Pediatr 152:263-269

10. Belsky J, Bakermans-Kranenburg M, van Itzendoorn M (2007) For better and for worse: Differential susceptibility to environmental influences. Current Directions In Psychological Science 16:300-304

11. Belsky J, Jonassaint C, Pluess M, Stanton M, Brummett B, Williams R (2009) Vulnerability 
genes or plasticity genes? Mol Psychiatry 14:746754

12. Blomeyer D, Treutlein J, Esser G, Schmidt MH, Schumann G, Laucht M (2008) Interaction between CRHR1 gene and stressful life events predicts adolescent heavy alcohol use. Biol Psychiatry 63:146-151

13. Bouchard C (2008) Gene-environment interactions in the etiology of obesity: defining the fundamentals. Obesity (Silver Spring) 16 Suppl 3:S5-S10

14. Bray MS (2008) Implications of gene-behavior interactions: prevention and intervention for obesity. Obesity (Silver Spring) 16 Suppl 3:S72-78

15. Brookes KJ, Mill J, Guindalini C, Curran S, Xu X, Knight J, Chen CK, Huang YS, Sethna V, Taylor E, Chen W, Breen G, Asherson P (2006) A common haplotype of the dopamine transporter gene associated with attention-deficit/hyperactivity disorder and interacting with maternal use of alcohol during pregnancy. Arch Gen Psychiatry 63:74-81

16. Brookes ST, Whitley E, Peters TJ, Mulheran PA, Egger M, Davey Smith G (2001) Subgroup analyses in randomised controlled trials: quantifying the risks of false-positives and falsenegatives. Health Technol Assess 5:1-56

17. Brown GW, Harris TO (2008) Depression and the serotonin transporter 5-HTTLPR polymorphism: a review and a hypothesis concerning geneenvironment interaction. J Affect Disord 111:1-12

18. Caspi A, McClay J, Moffitt TE, Mill J, Martin J, Craig IW, Taylor A, Poulton R (2002) Role of genotype in the cycle of violence in maltreated children. Science 297:851-854

19. Caspi A, Moffitt TE (2006) Gene-environment interactions in psychiatry: joining forces with neuroscience. Nat Rev Neurosci 7:583-590

20. Caspi A, Moffitt TE, Cannon M, McClay J, Murray R, Harrington H, Taylor A, Arseneault L, Williams B, Braithwaite A, Poulton R, Craig IW (2005) Moderation of the effect of adolescentonset cannabis use on adult psychosis by a functional polymorphism in the catechol-Omethyltransferase gene: longitudinal evidence of a gene $\mathrm{X}$ environment interaction. Biol Psychiatry 57:1117-1127

21. Caspi A, Sugden K, Moffitt TE, Taylor A, Craig IW, Harrington H, McClay J, Mill J, Martin J, Braithwaite A, Poulton R (2003) Influence of life stress on depression: moderation by a polymorphism in the 5-HTT gene. Science 301:386-389

22. Cervilla JA, Molina E, Rivera M, Torres-Gonzalez F, Bellon JA, Moreno B, Luna JD, Lorente JA, 
Mayoral F, King M, Nazareth I, Gutierrez B (2007) The risk for depression conferred by stressful life events is modified by variation at the

23. Chipman P, Jorm AF, Prior M, Sanson A, Smart D, Tan X, Easteal S (2007) No interaction between the serotonin transporter polymorphism (5HTTLPR) and childhood adversity or recent stressful life events on symptoms of depression: results from two community surveys. Am J Med Genet B Neuropsychiatr Genet 144B:561-565

24. Chorbov VM, Lobos EA, Todorov AA, Heath AC, Botteron KN, Todd RD (2007) Relationship of 5HTTLPR genotypes and depression risk in the presence of trauma in a female twin sample. Am J Med Genet B Neuropsychiatr Genet 144B:830-833

25. Cloninger CR, Sigvardsson S, Gilligan SB, von Knorring AL, Reich T, Bohman M (1988) Genetic heterogeneity and the classification of alcoholism. Adv Alcohol Subst Abuse 7:3-16

26. Coghill D, Banaschewski T (2009) The genetics of attention-deficit/hyperactivity disorder. Expert Rev Neurother 9:1547-1565

27. Covault J, Tennen H, Armeli S, Conner TS, Herman AI, Cillessen AH, Kranzler HR (2007) Interactive effects of the serotonin transporter 5HTTLPR polymorphism and stressful life events on college student drinking and drug use. Biol Psychiatry 61:609-616

28. Dempfle A, Scherag A, Hein R, Beckmann L, Chang-Claude J, Schafer H (2008) Geneenvironment interactions for complex traits: definitions, methodological requirements and challenges. Eur J Hum Genet 16:1164-1172

29. Drachmann Bukh J, Bock C, Vinberg M, Werge T, Gether U, Vedel Kessing L (2009) Interaction between genetic polymorphisms and stressful life events in first episode depression. J Affect Disord 119:107-115

30. Eaves LJ (2006) Genotype x Environment interaction in psychopathology: fact or artifact? Twin Res Hum Genet 9:1-8

31. El-Faddagh M, Laucht M, Maras A, Vohringer L, Schmidt MH (2004) Association of dopamine D4 receptor (DRD4) gene with attentiondeficit/hyperactivity disorder (ADHD) in a highrisk community sample: a longitudinal study from birth to 11 years of age. J Neural Transm 111:883889

32. El Hage W, Powell JF, Surguladze SA (2009) Vulnerability to depression: what is the role of stress genes in gene $\mathrm{x}$ environment interaction? Psychol Med:1-5 
33. Eley TC, Sugden K, Corsico A, Gregory AM, Sham P, McGuffin P, Plomin R, Craig IW (2004) Gene-environment interaction analysis of serotonin system markers with adolescent depression. Mol Psychiatry 9:908-915

34. Faraone SV, Perlis RH, Doyle AE, Smoller JW, Goralnick JJ, Holmgren MA, Sklar P (2005)

Molecular genetics of attentiondeficit/hyperactivity disorder. Biol Psychiatry 57:1313-1323

35. Feder A, Nestler EJ, Charney DS (2009) Psychobiology and molecular genetics of resilience. Nat Rev Neurosci 10:446-457

36. Ficks CA, Waldman ID (2009) Gene-environment interactions in attention-deficit/hyperactivity disorder. Curr Psychiatry Rep 11:387-392

37. Flint J, Munafo MR (2008) Forum: Interactions between gene and environment. Curr Opin Psychiatry 21:315-317

38. Foley DL, Eaves LJ, Wormley B, Silberg JL, Maes HH, Kuhn J, Riley B (2004) Childhood adversity, monoamine oxidase a genotype, and risk for conduct disorder. Arch Gen Psychiatry 61:738-744

39. Gillespie NA, Whitfield JB, Williams B, Heath AC, Martin NG (2005) The relationship between stressful life events, the serotonin transporter (5HTTLPR) genotype and major depression. Psychol Med 35:101-111

40. Goldman D, Oroszi G, Ducci F (2005) The genetics of addictions: uncovering the genes. Nat Rev Genet 6:521-532

41. Grabe HJ, Lange M, Wolff B, Volzke H, Lucht M, Freyberger HJ, John U, Cascorbi I (2005) Mental and physical distress is modulated by a polymorphism in the 5-HT transporter gene interacting with social stressors and chronic disease burden. Mol Psychiatry 10:220-224

42. Haberstick BC, Lessem JM, Hopfer CJ, Smolen A, Ehringer MA, Timberlake D, Hewitt JK (2005) Monoamine oxidase A (MAOA) and antisocial behaviors in the presence of childhood and adolescent maltreatment. Am J Med Genet B Neuropsychiatr Genet 135B:59-64

43. Hariri AR, Mattay VS, Tessitore A, Kolachana B, Fera F, Goldman D, Egan MF, Weinberger DR (2002) Serotonin transporter genetic variation and the response of the human amygdala. Science 297:400-403

44. Henquet C, Di Forti M, Morrison P, Kuepper R, Murray RM (2008) Gene-environment interplay between cannabis and psychosis. Schizophr Bull 34:1111-1121

45. Henquet C, Rosa A, Krabbendam L, Papiol S, Fananas L, Drukker M, Ramaekers JG, van Os J (2006) An experimental study of catechol-o- 
methyltransferase Val158Met moderation of delta-

9-tetrahydrocannabinol-induced effects on

psychosis and cognition.

Neuropsychopharmacology 31:2748-2757

46. Hunter DJ (2005) Gene-environment interactions in human diseases. Nat Rev Genet 6:287-298

47. Ioannidis JP, Ntzani EE, Trikalinos TA, Contopoulos-Ioannidis DG (2001) Replication validity of genetic association studies. Nat Genet 29:306-309

48. Ioannidis JP, Trikalinos TA (2007) An exploratory test for an excess of significant findings. Clin Trials 4:245-253

49. Kahn RS, Khoury J, Nichols WC, Lanphear BP (2003) Role of dopamine transporter genotype and maternal prenatal smoking in childhood hyperactive-impulsive, inattentive, and oppositional behaviors. J Pediatr 143:104-110

50. Kaufman J, Yang BZ, Douglas-Palumberi H, Crouse-Artus M, Lipschitz D, Krystal JH, Gelernter J (2007) Genetic and environmental predictors of early alcohol use. Biol Psychiatry 61:1228-1234

51. Kendler KS, Karkowski LM, Prescott CA (1999) Causal relationship between stressful life events and the onset of major depression. Am J Psychiatry 156:837-841

52. Keri S, Kiss I, Seres I, Kelemen O (2009) A polymorphism of the neuregulin 1 gene (SNP8NRG243177/rs6994992) affects reactivity to expressed emotion in schizophrenia. Am J Med Genet B Neuropsychiatr Genet 150B:418-420

53. Khoury MJ, Adams MJ, Jr., Flanders WD (1988) An epidemiologic approach to ecogenetics. Am J Hum Genet 42:89-95

54. Kim-Cohen J, Caspi A, Taylor A, Williams B, Newcombe R, Craig IW, Moffitt TE (2006) MAOA, maltreatment, and gene-environment interaction predicting children's mental health: new evidence and a meta-analysis. Mol Psychiatry 11:903-913

55. Kim JM, Stewart R, Kim SW, Yang SJ, Shin IS, Kim YH, Yoon JS (2007) Interactions between life stressors and susceptibility genes (5-HTTLPR and BDNF) on depression in Korean elders. Biol Psychiatry 62:423-428

56. Langley K, Fowler TA, Grady DL, Moyzis RK, Holmans PA, van den Bree MB, Owen MJ, O'Donovan MC, Thapar A (2009) Molecular genetic contribution to the developmental course of attention-deficit hyperactivity disorder. Eur Child Adolesc Psychiatry 18:26-32

57. Langley K, Turic D, Rice F, Holmans P, van den Bree MB, Craddock N, Kent L, Owen MJ, O'Donovan MC, Thapar A (2008) Testing for gene 
$x$ environment interaction effects in attention

deficit hyperactivity disorder and associated antisocial behavior. Am J Med Genet B

Neuropsychiatr Genet 147B:49-53

58. Laucht M, Skowronek MH, Becker K, Schmidt MH, Esser G, Schulze TG, Rietschel M (2007) Interacting effects of the dopamine transporter gene and psychosocial adversity on attentiondeficit/hyperactivity disorder symptoms among 15year-olds from a high-risk community sample. Arch Gen Psychiatry 64:585-590

59. Laucht M, Treutlein J, Blomeyer D, Buchmann AF, Schmid B, Becker K, Zimmermann US, Schmidt MH, Esser G, Rietschel M, Banaschewski $\mathrm{T}$ (2009) Interaction between the 5-HTTLPR serotonin transporter polymorphism and environmental adversity for mood and anxiety psychopathology: evidence from a high-risk community sample of young adults. Int $\mathbf{J}$ Neuropsychopharmacol:1-11

60. Laucht M, Treutlein J, Schmid B, Blomeyer D, Becker K, Buchmann AF, Schmidt MH, Esser G, Jennen-Steinmetz C, Rietschel M, Zimmermann US, Banaschewski T (2009) Impact of psychosocial adversity on alcohol intake in young adults: moderation by the LL genotype of the serotonin transporter polymorphism. Biol Psychiatry 66:102-109

61. Levin BE (2009) Synergy of nature and nurture in the development of childhood obesity. Int J Obes (Lond) 33 Suppl 1:S53-56

62. Loos RJ, Bouchard C (2008) FTO: the first gene contributing to common forms of human obesity. Obes Rev 9:246-250

63. Luan JA, Wong MY, Day NE, Wareham NJ (2001) Sample size determination for studies of gene-environment interaction. Int J Epidemiol 30:1035-1040

64. Manolio TA, Bailey-Wilson JE, Collins FS (2006) Genes, environment and the value of prospective cohort studies. Nat Rev Genet 7:812-820

65. Middeldorp CM, Cath DC, Beem AL, Willemsen G, Boomsma DI (2008) Life events, anxious depression and personality: a prospective and genetic study. Psychol Med 38:1557-1565

66. Middeldorp CM, de Geus EJ, Beem AL, Lakenberg N, Hottenga JJ, Slagboom PE, Boomsma DI (2007) Family based association analyses between the serotonin transporter gene polymorphism (5-HTTLPR) and neuroticism, anxiety and depression. Behav Genet 37:294-301

67. Mittal VA, Ellman LM, Cannon TD (2008) Geneenvironment interaction and covariation in schizophrenia: the role of obstetric complications. Schizophr Bull 34:1083-1094 
68. Moffitt TE, Caspi A, Rutter M (2006) Measured

Gene-Environment Interactions in

Psychopathology : Concepts, Research Strategies, and Implications for Research, Intervention, and Public Understanding of Genetics. Perspect Psychol Sci 1:5-27

69. Moffitt TE, Caspi A, Rutter M (2005) Strategy for investigating interactions between measured genes and measured environments. Arch Gen Psychiatry 62:473-481

70. Munafo MR, Durrant C, Lewis G, Flint J (2009) Gene $\mathrm{X}$ environment interactions at the serotonin transporter locus. Biol Psychiatry 65:211-219

71. Neuman RJ, Lobos E, Reich W, Henderson CA, Sun LW, Todd RD (2007) Prenatal smoking exposure and dopaminergic genotypes interact to cause a severe ADHD subtype. Biol Psychiatry 61:1320-1328

72. Nicodemus KK, Marenco S, Batten AJ, Vakkalanka R, Egan MF, Straub RE, Weinberger DR (2008) Serious obstetric complications interact with hypoxia-regulated/vascular-expression genes to influence schizophrenia risk. Mol Psychiatry 13:873-877

73. Nilsson KW, Sjoberg RL, Damberg M, Alm PO, Ohrvik J, Leppert J, Lindstrom L, Oreland L (2005) Role of the serotonin transporter gene and family function in adolescent alcohol consumption. Alcohol Clin Exp Res 29:564-570

74. Nilsson KW, Sjoberg RL, Damberg M, Leppert J, Ohrvik J, Alm PO, Lindstrom L, Oreland L (2006) Role of monoamine oxidase A genotype and psychosocial factors in male adolescent criminal activity. Biol Psychiatry 59:121-127

75. Olsson CA, Byrnes GB, Lotfi-Miri M, Collins V, Williamson R, Patton C, Anney RJ (2005)

Association between 5-HTTLPR genotypes and persisting patterns of anxiety and alcohol use: results from a 10-year longitudinal study of adolescent mental health. Mol Psychiatry 10:868876

76. Plomin R, DeFries JC, Loehlin JC (1977) Genotype-environment interaction and correlation in the analysis of human behavior. Psychol Bull 84:309-322

77. Power T, Stewart R, Ancelin ML, Jaussent I, Malafosse A, Ritchie K (2008) 5-HTTLPR genotype, stressful life events and late-life depression: No evidence of interaction in a French population. Neurobiol Aging

78. Psychogiou L, Daley DM, Thompson MJ, SonugaBarke EJ (2008) Do maternal attentiondeficit/hyperactivity disorder symptoms exacerbate or ameliorate the negative effect of child attention- 
deficit/hyperactivity disorder symptoms on parenting? Dev Psychopathol 20:121-137

79. Rampersaud E, Mitchell BD, Pollin TI, Fu M, Shen H, O'Connell JR, Ducharme JL, Hines S, Sack P, Naglieri R, Shuldiner AR, Snitker S (2008) Physical activity and the association of common FTO gene variants with body mass index and obesity. Arch Intern Med 168:1791-1797

80. Risch N, Herrell R, Lehner T, Liang KY, Eaves L, Hoh J, Griem A, Kovacs M, Ott J, Merikangas KR (2009) Interaction between the serotonin transporter gene (5-HTTLPR), stressful life events, and risk of depression: a meta-analysis. Jama 301:2462-2471

81. Rutter M (2008) Biological implications of geneenvironment interaction. J Abnorm Child Psychol 36:969-975

82. Rutter M (2003) Commentary: Nature-nurture interplay in emotional disorders. J Child Psychol Psychiatry 44:934-944

83. Rutter M (2007) Gene-environment interdependence. Dev Sci 10:12-18

84. Rutter M (2006) Implications of resilience concepts for scientific understanding. Ann N Y Acad Sci 1094:1-12

85. Rutter M (2002) The interplay of nature, nurture, and developmental influences: the challenge ahead for mental health. Arch Gen Psychiatry 59:9961000

86. Rutter M, Beckett C, Castle J, Colvert E, Kreppner JM, Metha M, Stevens SE, Sonuga-Barke EJ (2007) Effects of profound early institutional deprivation: An overwiev of findings from a UK longitudinal study of Romanian adoptees. Eur J Dev Psychol 4:332-350

87. Rutter M, Moffitt TE, Caspi A (2006) Geneenvironment interplay and psychopathology: multiple varieties but real effects. J Child Psychol Psychiatry 47:226-261

88. Rutter M, Silberg J (2002) Gene-environment interplay in relation to emotional and behavioral disturbance. Annu Rev Psychol 53:463-490

89. Rutter M, Silberg J, O'Connor T, Simonoff E (1999) Genetics and child psychiatry: I Advances in quantitative and molecular genetics. J Child Psychol Psychiatry 40:3-18

90. Schmid B, Blomeyer D, Treutlein J, Zimmermann US, Buchmann AF, Schmidt MH, Esser G, Rietschel M, Banaschewski T, Schumann G, Laucht M (2009) Interacting effects of CRHR1 gene and stressful life events on drinking initiation and progression among 19-year-olds. Int J Neuropsychopharmacol:1-12

91. Serretti A, Mandelli L, Lorenzi C, Pirovano A, Olgiati P, Colombo C, Smeraldi E (2007) 
Serotonin transporter gene influences the time course of improvement of "core" depressive and somatic anxiety symptoms during treatment with SSRIs for recurrent mood disorders. Psychiatry Res 149:185-193

92. Shaw P, Gornick M, Lerch J, Addington A, Seal J, Greenstein D, Sharp W, Evans A, Giedd JN, Castellanos FX, Rapoport JL (2007)

Polymorphisms of the dopamine D4 receptor, clinical outcome, and cortical structure in attention-deficit/hyperactivity disorder. Arch Gen Psychiatry 64:921-931

93. Sinha R (2001) How does stress increase risk of drug abuse and relapse? Psychopharmacology (Berl) 158:343-359

94. Smeraldi E, Zanardi R, Benedetti F, Di Bella D, Perez J, Catalano M (1998) Polymorphism within the promoter of the serotonin transporter gene and antidepressant efficacy of fluvoxamine. Mol Psychiatry 3:508-511

95. Sonuga-Barke EJ, Lasky-Su J, Neale BM, Oades R, Chen W, Franke B, Buitelaar J, Banaschewski T, Ebstein R, Gill M, Anney R, Miranda A, Mulas F, Roeyers H, Rothenberger A, Sergeant J, Steinhausen HC, Thompson M, Asherson P, Faraone SV (2008) Does parental expressed emotion moderate genetic effects in ADHD? An exploration using a genome wide association scan. Am J Med Genet B Neuropsychiatr Genet 147B:1359-1368

96. Sonuga-Barke EJ, Oades RD, Psychogiou L, Chen W, Franke B, Buitelaar J, Banaschewski T, Ebstein RP, Gil M, Anney R, Miranda A, Roeyers H, Rothenberger A, Sergeant J, Steinhausen HC, Thompson M, Asherson P, Faraone SV (2009) Dopamine and serotonin transporter genotypes moderate sensitivity to maternal expressed emotion: the case of conduct and emotional problems in attention deficit/hyperactivity disorder. J Child Psychol Psychiatry 50:1052-1063

97. Sonuga-Barke EJ, Rubia K (2008) Inattentive/overactive children with histories of profound institutional deprivation compared with standard ADHD cases: a brief report. Child Care Health Dev 34:596-602

98. Stefansson H, Ophoff RA, Steinberg S, Andreassen OA, Cichon S, Rujescu D, Werge T, Pietilainen OP, Mors O, Mortensen PB, Sigurdsson E, Gustafsson O, Nyegaard M, Tuulio-Henriksson A, Ingason A, Hansen T, Suvisaari J, Lonnqvist J, Paunio T, Borglum AD, Hartmann A, Fink-Jensen A, Nordentoft M, Hougaard D, Norgaard-Pedersen B, Bottcher Y, Olesen J, Breuer R, Moller HJ, Giegling I, Rasmussen HB, Timm S, Mattheisen M, Bitter I, Rethelyi JM, Magnusdottir BB, 
Sigmundsson T, Olason P, Masson G, Gulcher JR, Haraldsson M, Fossdal R, Thorgeirsson TE, Thorsteinsdottir U, Ruggeri M, Tosato S, Franke B, Strengman E, Kiemeney LA, Melle I, Djurovic S, Abramova L, Kaleda V, Sanjuan J, de Frutos R, Bramon E, Vassos E, Fraser G, Ettinger U, Picchioni M, Walker N, Toulopoulou T, Need AC, Ge D, Yoon JL, Shianna KV, Freimer NB, Cantor RM, Murray R, Kong A, Golimbet V, Carracedo A, Arango C, Costas J, Jonsson EG, Terenius L, Agartz I, Petursson H, Nothen MM, Rietschel M, Matthews PM, Muglia P, Peltonen L, St Clair D, Goldstein DB, Stefansson K, Collier DA (2009) Common variants conferring risk of schizophrenia. Nature 460:744-747

99. Stevens SE, Kumsta R, Kreppner JM, Brookes KJ, Rutter M, Sonuga-Barke EJ (2009) Dopamine transporter gene polymorphism moderates the effects of severe deprivation on ADHD symptoms: developmental continuities in gene-environment interplay. Am J Med Genet B Neuropsychiatr Genet 150B:753-761

100. Stevens SE, Sonuga-Barke EJ, Kreppner JM, Beckett C, Castle J, Colvert E, Groothues C, Hawkins A, Rutter M (2008) Inattention/overactivity following early severe institutional deprivation: presentation and associations in early adolescence. $\mathrm{J}$ Abnorm Child Psychol 36:385-398

101. Surtees PG, Wainwright NW, Willis-Owen SA, Luben R, Day NE, Flint J (2006) Social adversity, the serotonin transporter (5-HTTLPR) polymorphism and major depressive disorder. Biol Psychiatry 59:224-229

102. Takeshita T, Mao XQ, Morimoto K (1996) The contribution of polymorphism in the alcohol dehydrogenase beta subunit to alcohol sensitivity in a Japanese population. Hum Genet 97:409-413

103. Taylor SE, Way BM, Welch WT, Hilmert CJ, Lehman BJ, Eisenberger NI (2006) Early family environment, current adversity, the serotonin transporter promoter polymorphism, and depressive symptomatology. Biol Psychiatry 60:671-676

104. Thapar A, Harold G, Rice F, Langley K, O'Donovan M (2007) The contribution of geneenvironment interaction to psychopathology. Dev Psychopathol 19:989-1004

105. Thapar A, Langley K, Asherson P, Gill M (2007) Gene-environment interplay in attention-deficit hyperactivity disorder and the importance of a developmental perspective. Br J Psychiatry 190:13

106. Thapar A, Langley K, Fowler T, Rice F, Turic D, Whittinger N, Aggleton J, Van den Bree M, Owen 
M, O'Donovan M (2005) Catechol Omethyltransferase gene variant and birth weight predict early-onset antisocial behavior in children with attention-deficit/hyperactivity disorder. Arch Gen Psychiatry 62:1275-1278

107. Uher R (2008) Gene-environment interaction: overcoming methodological challenges. Novartis Found Symp 293:13-26; discussion 26-30, 68-70

108. Uher R, McGuffin P (2008) The moderation by the serotonin transporter gene of environmental adversity in the aetiology of mental illness: review and methodological analysis. Mol Psychiatry 13:131-146

109. van Os J, Rutten BP, Poulton R (2008) Geneenvironment interactions in schizophrenia: review of epidemiological findings and future directions. Schizophr Bull 34:1066-1082

110. van Winkel R, Henquet C, Rosa A, Papiol S, Fananas L, De Hert M, Peuskens J, van Os J, Myin-Germeys I (2008) Evidence that the COMT(Val158Met) polymorphism moderates sensitivity to stress in psychosis: an experiencesampling study. Am J Med Genet B Neuropsychiatr Genet 147B:10-17

111. Wilhelm K, Mitchell PB, Niven H, Finch A, Wedgwood L, Scimone A, Blair IP, Parker G, Schofield PR (2006) Life events, first depression onset and the serotonin transporter gene. $\mathrm{Br} \mathrm{J}$ Psychiatry 188:210-215

112. Young SE, Smolen A, Hewitt JK, Haberstick BC, Stallings MC, Corley RP, Crowley TJ (2006) Interaction between MAO-A genotype and maltreatment in the risk for conduct disorder: failure to confirm in adolescent patients. Am J Psychiatry 163:1019-1025 